\title{
CORRECTION
}

Open Access

\section{Correction to: Effect of caffeine on delayed-onset muscle soreness: a meta-analysis of RCT}

Janisa Andrea Muljadi ${ }^{1}$, Patsorn Kaewphongsri ${ }^{2}$, Kornkit Chaijenkij ${ }^{3}$ and Jatupon Kongtharvonskul ${ }^{4,5^{*}}$

\section{Correction to: Bulletin of the National Research Centre (2021) 45:197 \\ https://doi.org/10.1186/s42269-021-00660-5}

Following publication of the original article [1], the authors identified an error in the author name of Janisa Andrea Muljadi.

The incorrect author name is: Janisa Andrea Maljadi.

The correct author name is: Janisa Andrea Muljadi.

The author group has been updated above, and the original article [1] has been corrected.

\section{Author details}

${ }^{1}$ Faculty of Medicine, Ramathibodi Hospital, Bangkok, Thailand. ${ }^{2}$ Mater Dei School, Bangkok, Thailand. ${ }^{3}$ Sports Medicine Center, College of Sports Science and Technology, Mahidol University, Nakhon Pathom, Thailand. ${ }^{4}$ Department of Epidemiology and Biostatistics, Faculty of Medicine, Ramathibodi Hospital, Bangkok, Thailand. ${ }^{5}$ Vejthani Hospital, Bangkok, Thailand.

Published online: 26 November 2021

\section{Reference \\ Muljadi et al (2021) Bulletin of the National Research Centre 45:197. https:// doi.org/10.1186/s42269-021-00660-5}

\section{Publisher's Note}

Springer Nature remains neutral with regard to jurisdictional claims in published maps and institutional affiliations.

${ }^{4}$ Department of Epidemiology and Biostatistics, Faculty of Medicine,

Ramathibodi Hospital, Bangkok, Thailand

Full list of author information is available at the end of the article

\section{Springer Open}

(c) The Author(s) 2021. Open Access This article is licensed under a Creative Commons Attribution 4.0 International License, which permits use, sharing, adaptation, distribution and reproduction in any medium or format, as long as you give appropriate credit to the original author(s) and the source, provide a link to the Creative Commons licence, and indicate if changes were made. The images or other third party material in this article are included in the article's Creative Commons licence, unless indicated otherwise in a credit line to the material. If material is not included in the article's Creative Commons licence and your intended use is not permitted by statutory regulation or exceeds the permitted use, you will need to obtain permission directly from the copyright holder. To view a copy of this licence, visit http://creativecommons.org/licenses/by/4.0/. 